三 宅 正二郎*1

\title{
Creation of Solid Lubricant Firms by Nanostructure Control
}

\author{
Shojiro MIYAKE*1 \\ ${ }^{* 1}$ Inovative Systems Engineering, Nippon Institute of Technology, 4-1 Gakuendai, Miyashiro-machi Minamisaitama-gun, \\ Saitama 345-8501, Japan
}

(Received July 31, 2014, Accepted January 29, 2015)

\begin{abstract}
The friction coefficient can be decreased by increasing the hardness of a sliding plane while maintaining low shear resistance parallel to its substrate using nanostructural control techniques. Herein, nanoperiodic multilayer films composed of solid lubricant materials were proposed to develop a new solid lubricant film having lower friction than that of conventional solid lubricant films. The applied solid lubricant materials were soft metals including Au and Ag, polymers such as PTFE (polytetrafluoroethylene), and crystallizing layered inorganic compounds such as $\mathrm{MoS}_{2}$ (molybdenum disulfide), $\mathrm{WS}_{2}$ (tungsten disulfide), graphite, and hexagonal-BN. The nanoindentation properties of the obtained films were evaluated. Multilayered films with a suitable period showed a high hardness and elastic modulus. These nanoperiod multilayer solid lubricant films exhibited lower friction, higher nanowear resistance, and superior friction endurance than those of monolayer films.
\end{abstract}

\section{1. はじめに}

最近機械が用いられる環境条件は急速に拡大しており，高 速, 高荷重, 高·低温, 真空, 清浄環境, 放射能, 反応ガス 雾囲気中など各種環境下で使用される機構部品の信頼性を確 保することが課題となっている.これらの分野は潤滑油のみ では摩擦耐久性などトライボロジ一特性が不十分な場合が多 く, 固体潤滑剤が応用されている. 代表的な固体潤滑剤は物 質自体がせん断変形されやすく, 低摩擦を示す. 従って薄膜 として用いる場合, 徐々に表面から離脱しやすく, 摩擦耐久 性に問題がある場合も多い1-3). 一方, 単一材料ではトライ ボロジ一特性を満足できない場合が多く, 複合化してナノ構 造を持たせ，特性を改善することが期待されている3-5). 例 えばナノ周期積層膜によりトライボロジ一特性の改善が試み られている. ナノ周期積層膜は, 膜厚が数 $\mathrm{nm}$ と極めて薄い 薄膜を積み重ねた構造である. 異なる物質を $\mathrm{nm}$ サイズで交 互に積み重ねると, その物質単体とは異なる特性が現れ る ${ }^{5-7)}$. 具体的にはナノ周期構造による内部エネルギー变化 に起因し, 積層膜自体の弾性率および硬度が増大する。

硬質膜として, $\mathrm{CNx} / \mathrm{TiN}^{6)}, \mathrm{TiN} / \mathrm{AlN}^{7)}$ などの積層膜の研 究が行われている. 著者らは, $\mathrm{CN}$ (窒化炭素) 膜および $\mathrm{BN}$ (窒化ホウ素) 膜を数 $\mathrm{nm}$ 単位で積層させた $\mathrm{CN} / \mathrm{BN}$ 積 層膜の研究を行っている ${ }^{8)}$. その結果, 数 $\mathrm{nm}$ 周期の積層膜 の形成が確認され, 硬さおよびナノ摩耗特性は積層周期依存 性を示し, 一定の積層周期で優れた機械特性が得られてい $ろ^{8,9)}$.

更に, これらのナノ周期積層膜について, 積層方向の弾性 率および硬さの増加および滑り面のせん断力が小さいことを 利用して, 従来よりも低摩擦を示す固体潤滑膜を検討してき た $3,4,10-14)$.ここではナノ構造制御により形成した固体潤滑 膜について著者らの検討結果を中心に報告する.

*1 日本工業大学創造システム工学科（テ345-8501 埼玉県南埼玉 郡宮代町学園台 4-1)

\section{2. 低摩擦化を実現するナノ構造薄膜の形成とそ の性質}

\section{1 低摩擦化のための表面材料構造}

低摩擦化のための材料構成としては, 硬質材料にせん断抵 抗の小さい薄膜を形成する方法が広く知られている1-3).

Fig. 1 に低摩擦実現のモデルを示す. 接触面積 A は, 構成 材料の剛性により小さくなり, せん断抵抗 $\mathrm{s}$ は表面材料のせ 几断抵抗が小さい材料を選べば, 摩擦力 $\mathrm{F}=\mathrm{sA}$ が低減でき る.このモデルでさらに摩擦を減少させるためには, 摩擦構 成材料の弾性率, 硬さを増大させれば良い。

固体潤滑膜においてもナノ構造を利用し, 積層方向の硬さ および弾性率を増大させ, 基板と平行な滑り面のせん断抵抗 を, 固体潤滑材料を用い低く保つことによって, 接触面積を 小さくし, 摩擦係数を減少できる ${ }^{9)}$. このように, ナノ周期 積層構造を利用すれば, 従来の単体膜や混合膜では得られな かった低摩擦が期待できる.

\section{2 ナノメータ構造制御による機械特性の向上}

ナノ周期積層膜の形成に用いたスパッタリング装置の一例 を Fig. 2 に示す. 2 種以上の固体潤滑材料をターゲットと し基板を設置し，回転により，金（Au）と銀（Ag）を交互 に層状に形成する．また，目標周期 $24 \mathrm{~nm}$ で形成した $\mathrm{TiC} /$ DLC 積層膜のSTEM ( Scanning transmission electron microscope）像を Fig. 3 に， $6 \mathrm{~nm}$ で形成したナノコンポシ ット膜を Fig. 4 に示す ${ }^{12)}$. 目標周期と構造の関係を Fig. 5 に示すが $12 \mathrm{~nm}$ 未満では粒子状のナノコンポジット膜になり, $12 \mathrm{~nm}$ 以上ではナノ周期積層膜が形成されている. ナノメー タの構造の積層膜を形成すれば, 硬さおよび弾性率は, 積層 させた各物質の単層膜よりも増大する. 例えば超硬質膜の構 成要素であるカーボン, ボロン, 窒素を構成元素とするナノ 周期積層構造を有する超硬質膜が検討されている8 ${ }^{8,9)}$.

ナノ周期積層 $(\mathrm{CN} / \mathrm{BN}) \mathrm{n}$ 膜 $\left.{ }^{8}\right)$ は積層周期により硬さが変 化し, 周期 $4 \mathrm{~nm}$ が最も硬く, 耐ナノ摩耗特性に優れてい る.ナノ周期積層膜の硬さ増大のメカニズムを追及するため 


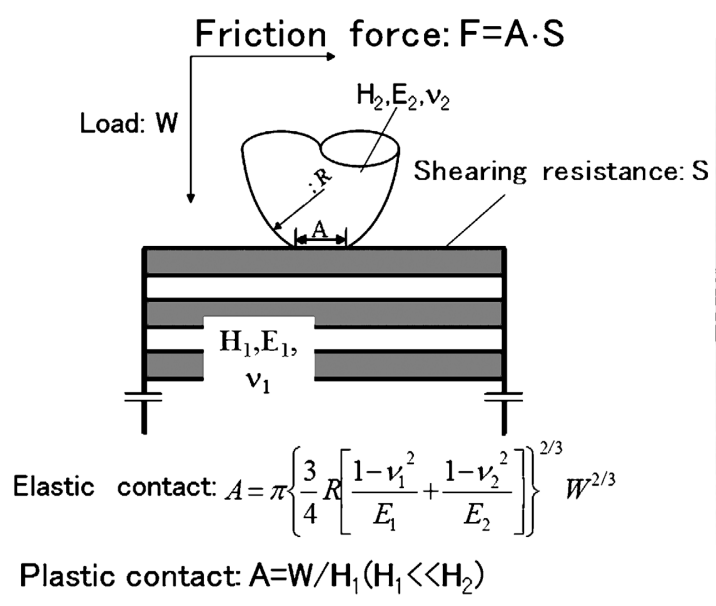

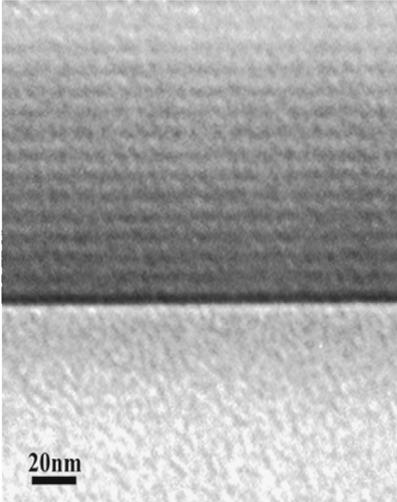

Silicon wafer

CN/BN multilayer film

Fig. 1 Model of decreasing of friction by nanoperiod multilayer film.

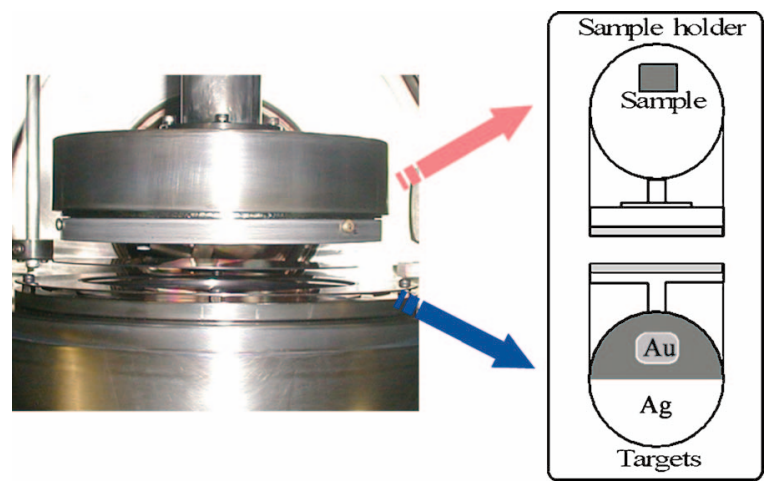

Fig. 2 Deposition method of $\mathrm{Au} / \mathrm{Ag}$ nanoperiod multilayer films ${ }^{8}$.

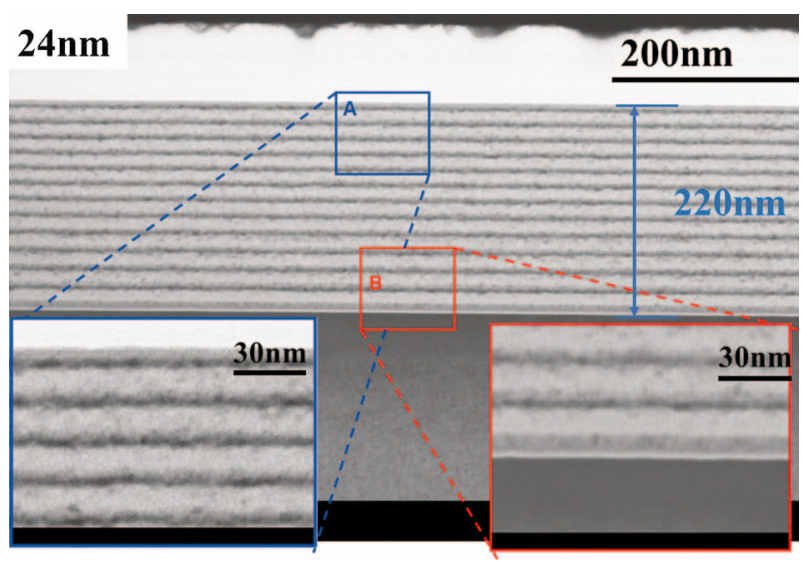

Fig. 3 24-nm target period $\mathrm{TiC} / \mathrm{DLC}$ multilayer films ${ }^{12)}$.

に AFM (Atomic Force Microscopy) を用い，原子単位のナ ノ摩耗試験を行った. Fig. 6 に示すように各種積層周期の 各層の厚さ，例えば $4 \mathrm{~nm}$ 周期の各層 $2 \mathrm{~nm}$ 毎に摩耗の進展 が停止する現象が観察された ${ }^{8,9}$ 。このように積層膜の境界 部で破壊の進展を抑止する効果があり，これが耐摩耗性向上 に寄与すると考えられる ${ }^{8,9)}$. また, 一定周期 $(4 \mathrm{~nm})$ で硬 さが最大になる現象を明らかにするため境界部の摩擦力分布

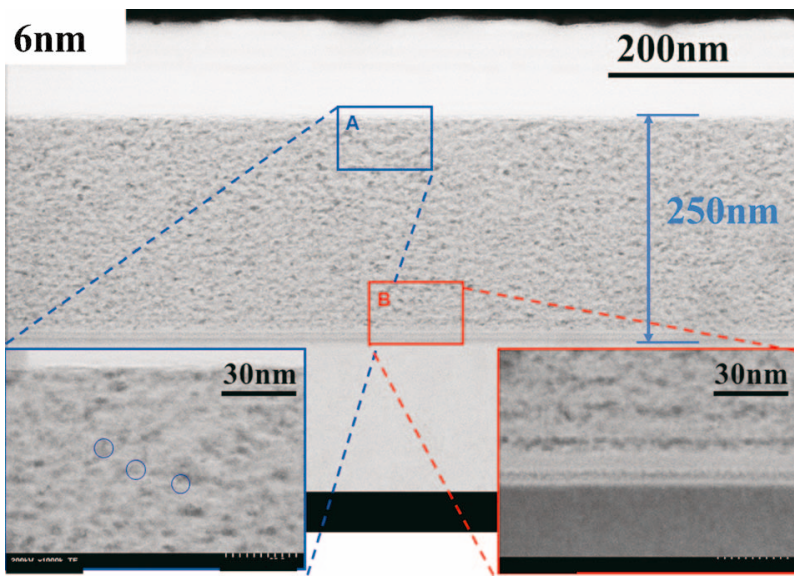

Fig. 4 6-nm target period nanocomposite TiC/DLC multilayer film ${ }^{12)}$.

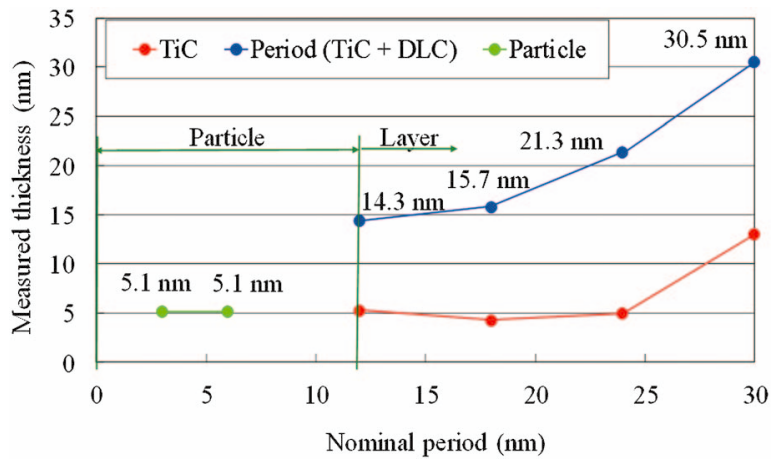

Fig. 5 Nanostructure of TiC/DLC film dependence on target thickness ${ }^{12)}$.

の変化を $\mathrm{AFM}$ のフォースモジュレーションにより求めた. 積層膜形成時のナノ構造のモデルを Fig. 7 に示す. $1 \mathrm{~nm}$ 膜 厚のカーボンと BN の境界部に Fig. 8 に示すように $0.6 \mathrm{~nm}$ 程度の組成傾斜部が摩擦振幅の差として検出される。これは 膜形成時のターゲットの切り替え時間と対応している．この 境界部の傾斜構造に起因して欠陥進展の抑止効果が变化する ことが明らかになっている13,14). 


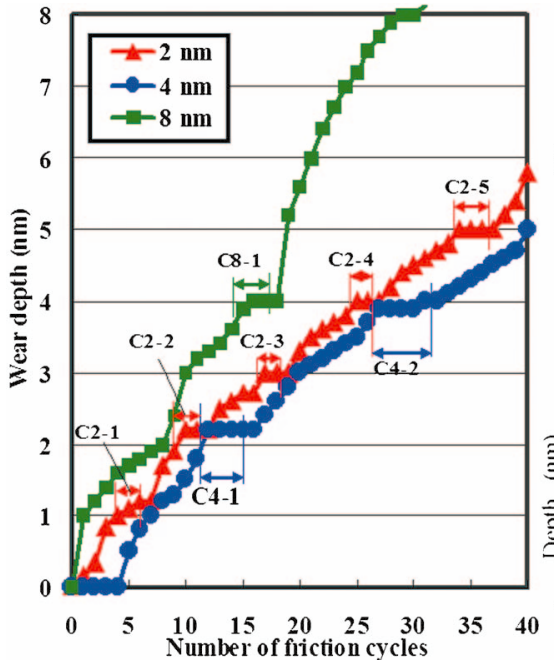

(a) Nanowear characteristics

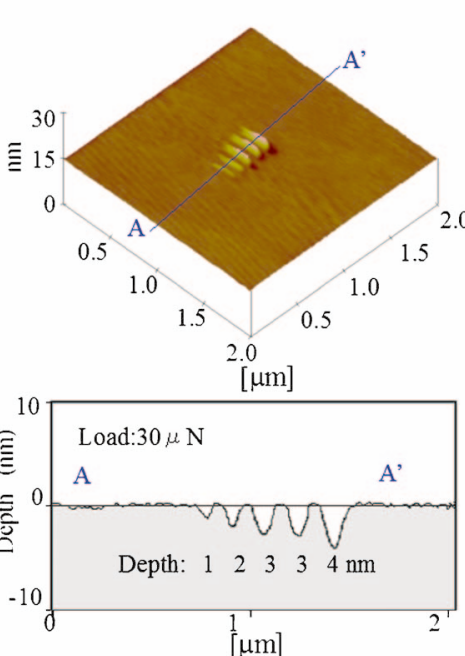

(b) Processing of multilayer unit

Fig. 6 Nanowear depth dependence on number of friction cycles for 2-, 4-, and 8-nm-layerperiod multilayer films ${ }^{9}$.

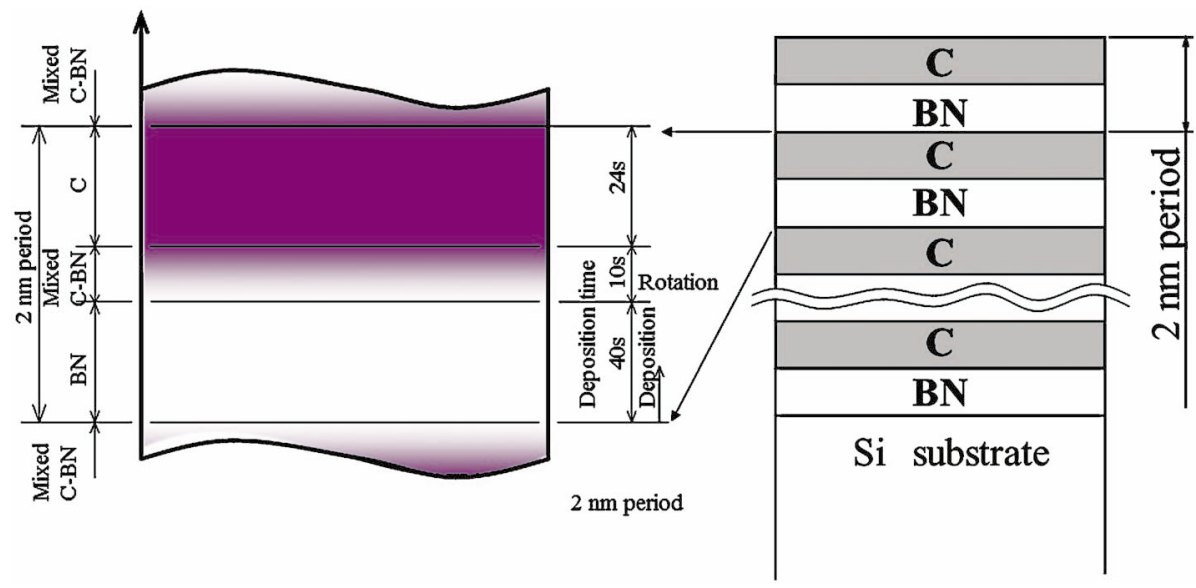

Fig. 7 Interface structural model of nanoperiod multilayer film ${ }^{13)}$.

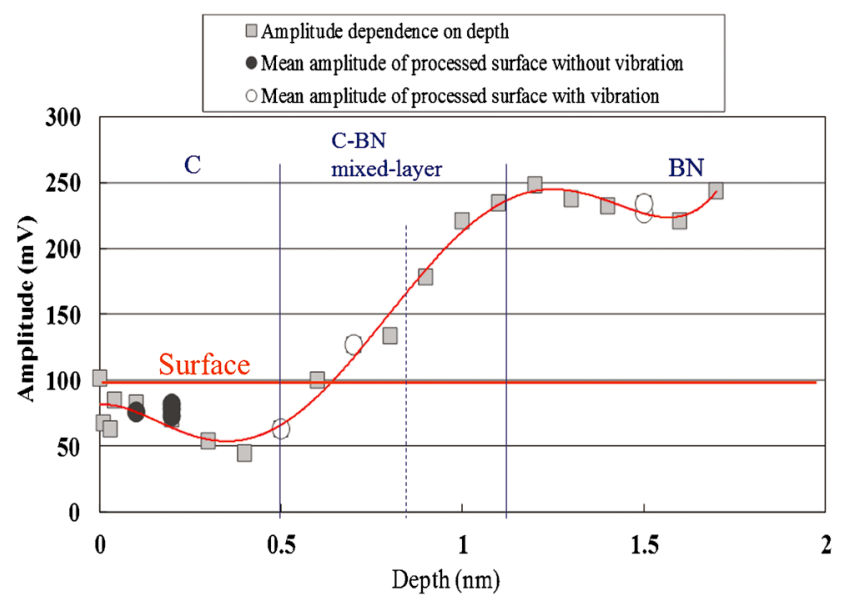

Fig. 8 Processing depth dependence of amplitude of tip cantilever displacement measured on processed surface ${ }^{13)}$.

\section{3. ナノ周期積層固体潤滑膜のトライボロジー特 性}

ここでは代表的な固体潤滑材料である(1) 軟質金属材料,
（2）層状結晶材料，(3) 耐摩耗性カーボン系材料を構成要素と するナノ周期積層膜を紹介する。

\section{1 軟質金属材料（ $\mathbf{A u}, \mathbf{A g} ）$ のナノ周期積層膜}

導電性で，優れたトライボロジ一特性を示す固体潤滑膜を 開発するため， $\mathrm{Au} と \mathrm{Ag} ， \mathrm{Au} と \mathrm{DLC}$ ( diamond-like carbon）抢よび Au と PTFEを積層したナノ周期積層固体 潤滑膜を形成した。 $\mathrm{Au}$ と $\mathrm{Ag}$ の積層膜の摩擦特性を Fig. 9 に示す ${ }^{15)}$ 。ナノ周期積層膜の摩擦係数は低い值を示す。ま た，摩擦が急増する摩擦回数で求めた摩擦耐久性は単層膜上 り著しく増大している。さらに摩擦試験後の電気抵抗率を Fig. 10に示すが単層膜, 混合膜の変化が大きいのに対し て，積層膜は安定して低い。この様に $\mathrm{Au} ， \mathrm{Ag}$ をナノメー 夕周期で積層することにより, 硬さ打よび弾性率が増大し, せん断抵抗が $\mathrm{Au}, \mathrm{Ag}$ の低い值に保たれることによって, 低摩擦を実現でき，更に摩擦寿命が著しく増大する。

導電性を有し，さらに耐摩耗性のある薄膜として金と DLC のナノ周期積層膜を検討している．Fig. 11に水の境界 潤滑条件下の摩擦特性を示す。積層膜は単層膜よりも各種条 件で安定して低摩擦を示している ${ }^{16)}$. 各種環境下の摩擦係 数の平均値を Fig. 12に示す. 積層膜は無潤滑, 水, 合成油 
$(\mathrm{PAO})$, 添加剂入り合成油 $(\mathrm{PAO}+\mathrm{GMO})$ による境界潤滑 のすべての条件で安定して低摩擦を示している. また下地側 への損傷進展が積層界面で防止される効果で摩擦耐久性も向 上している.

$\mathrm{Au}$ と PTFEのナノ周期積層膜と混合膜の水との接触角を Fig. 13に示す. PTFEを含んでいるので水との接触角が大 きく低エネルギ一表面となる，また，各種条件下に打嚤 擦係数を Fig. 14に示す. 適切な条件では摩擦係数も低く安 定している17)。さらにこれらの膜は導電性を有し, 下地側 への損傷進展が防止されるので摩擦耐久性が向上するなどユ ニークな特性が得られている。このように $\mathrm{Au}$ を含有したナ ノ周期積層膜は導電性を有し，低摩擦と長寿命を示すなど優 れた固体潤滑特性を示し, 接点などの導電性が必要な部品へ の応用展開が期待できる.

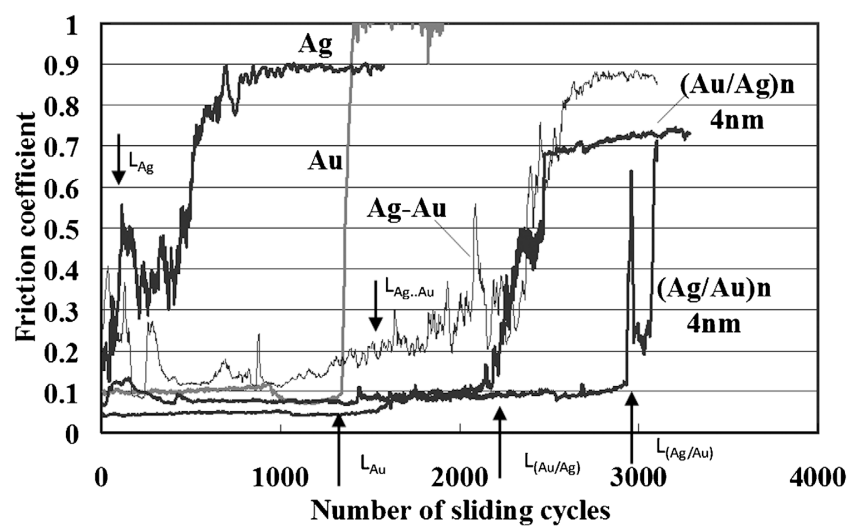

Fig. 9 Friction coefficient of $\mathrm{Ag} / \mathrm{Au}$ multilayer film dependence on sliding cycles ${ }^{15)}$.

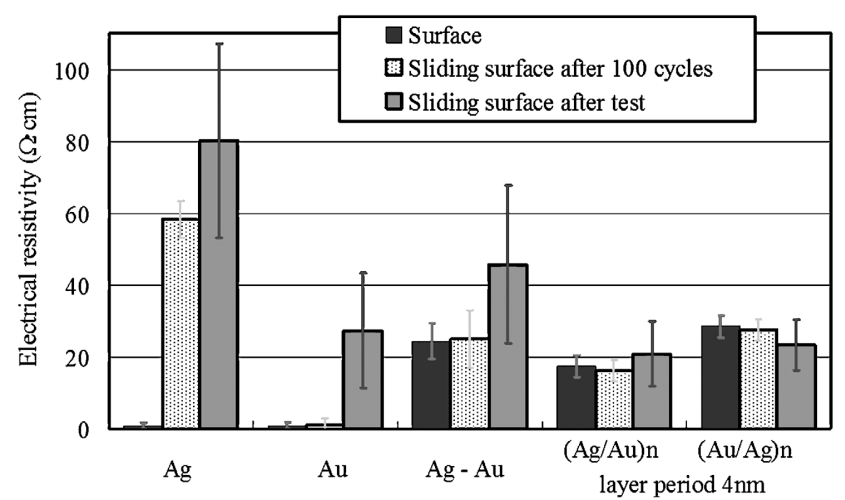

Fig. 10 Electrical resistivity after sliding test $\mathrm{t}^{15)}$.

\section{2 層状結晶材料 $\left(\mathrm{MoS}_{2}, \mathrm{WS}_{2}\right)$ のナノ周期積層膜}

宇宙空間, 各種真空装置駆動部などに使用され, 低摩擦を 示す二硫化モリブデン $\left(\mathrm{MoS}_{2}\right)$, 二硫化タングステン $\left(\mathrm{WS}_{2}\right)$ についてもナノ周期積層膜を形成すれば硬さが増大し, 単層 膜よりも優れた固体潤滑効果が得られる ${ }^{18)}$. 薄膜の機械特 性の評価を行うためナノインデンテーション試験を行った.

Fig. 15に $\mathrm{WS}_{2}, \mathrm{MoS}_{2}$ スパッタ膜のナノインデンテーショ ンカーブの例を示す. 単層膜の最大変形深さ, 塑性変形深さ は大きいが積層膜では著しく減少している，荷重を変化させ て測定したナノインデンテーション硬さは Fig. 16に示すよ うに 2 倍以上に増大している.

ボールオンディスク形摩擦試験機により評価した $\mathrm{WS}_{2} /$ $\mathrm{MoS}_{2}$ ナノ周期積層膜の摩擦特性を Fig. 17に示す ${ }^{18)}$. 積層

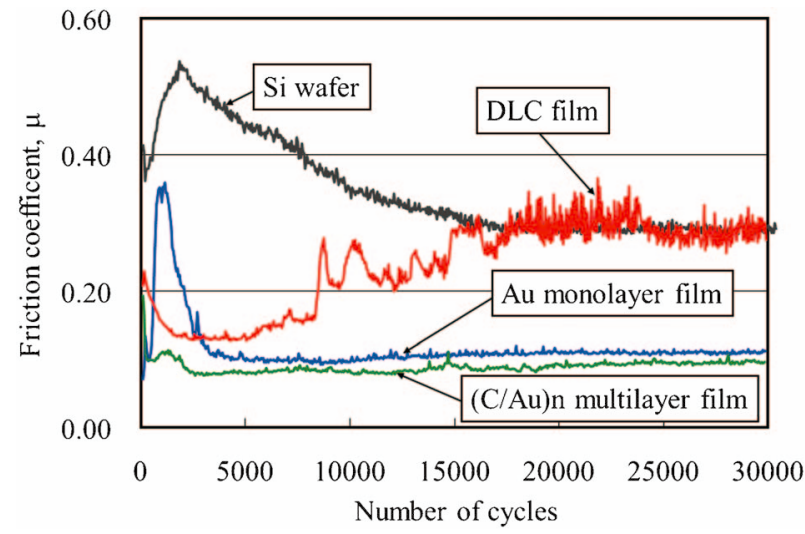

Fig. 11 Friction coefficient dependence on sliding cycle under distilled water boundary lubrication ${ }^{16)}$.

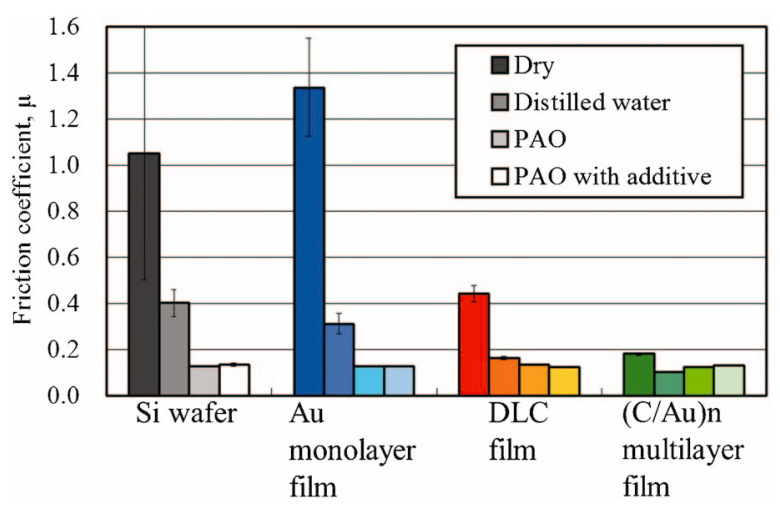

Fig. 12 Average friction coefficients during oscillating sliding tests $^{16)}$.

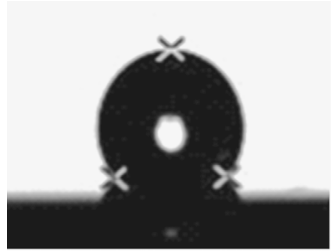

(a) Higher power Mixed film (5)

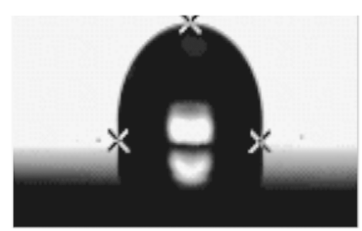

(c) Higher power $(\mathrm{Au} / \mathrm{PTFE}) \mathrm{n}$

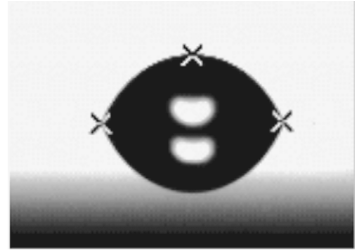

(e) Si wafer

Fig. 13 Contact angle of various $\mathrm{Au}-\mathrm{PTFE}$ composite films ${ }^{17)}$. 
周期 $10 \mathrm{~nm}$ と $20 \mathrm{~nm}$ を比較すると $20 \mathrm{~nm}$ では $\mu=0.1$ を示す が，積層周期 $10 \mathrm{~nm}$ の積層膜は特に低摩擦で $\mu=0.04$ 程度に なる．単層膜は湿度の影響により大気中で寿命が低下する傾 向が知られて抢り，摩擦係数も比較的大きく，摩擦が急増す る摩擦寿命は $10^{4}$ 以下になっている.これに対して, $10 \mathrm{~nm}$ 周期の積層膜は低摩擦で 6000 回以上の長寿命を示してい る. 単層膜の摩耗深さは, 局所的には膜厚 $400 \mathrm{~nm}$ に達して おり, 基板を露出させ, 摩擦が急速に増加している.これに 対して, 積層固体潤滑膜の摩耗深さは, $150 \mathrm{~nm}$ 程度で摺動 面に残存し，最終的な摩擦寿命に達しなかった。このように

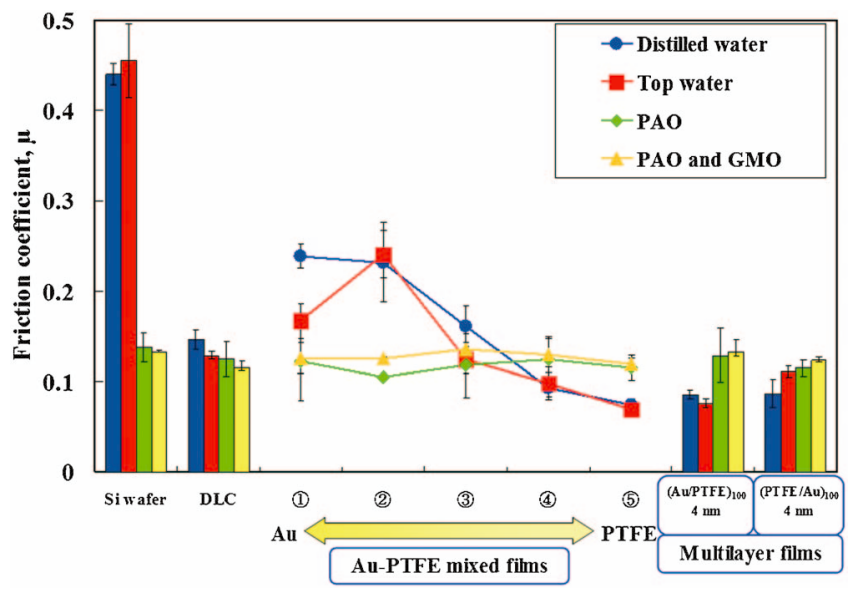

Fig. 14 Friction coefficient of various Au-PTFE composite films ${ }^{17)}$.

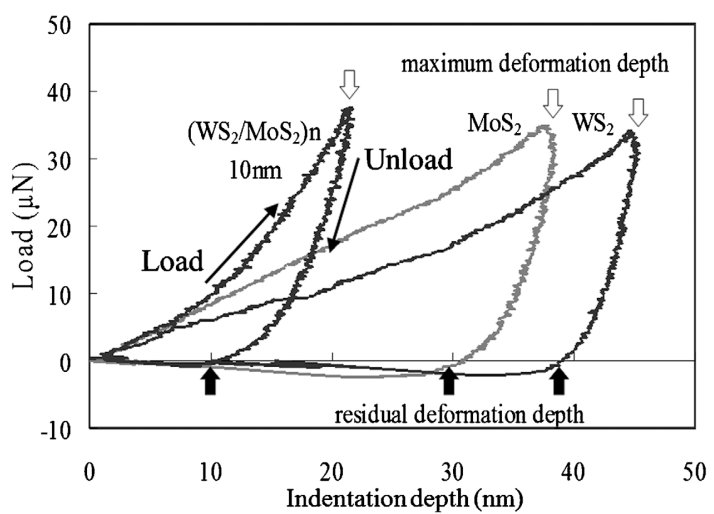

Fig. 15 Nanoindentaion curves of $\mathrm{WS}_{2} / \mathrm{MoS}_{2}$ multilayer film ${ }^{18)}$.

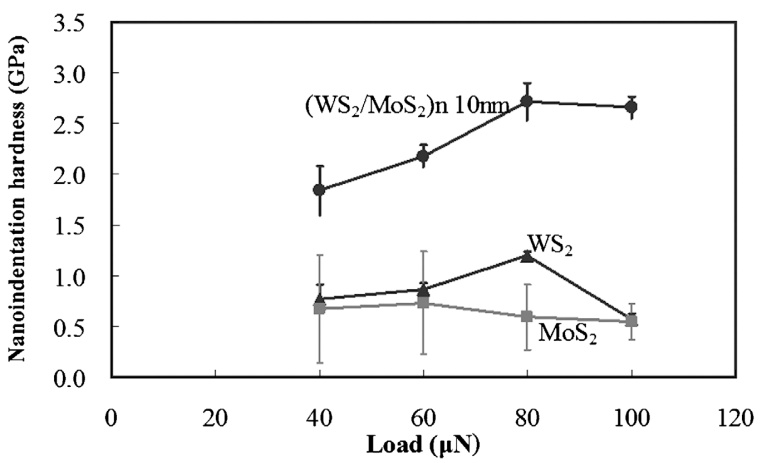

Fig. 16 Hardness of $\mathrm{WS}_{2} / \mathrm{MoS}_{2}$ multilayer films ${ }^{18)}$.
摩擦により生じる欠陥の深さ方向への進展が境界層により妨 げられるので摩擦耐久性も向上している.さらに真空中では 摩擦係数 0.01 程度の極低摩擦を示し，長寿命が得られる ${ }^{19)}$. また，DLC と $\mathrm{MoS}_{2}$ の積層膜は摩擦耐久性が著しく向上す $ろ^{20)}$.

\section{3 耐摩耗カーボン系（C/BN, TiC/DLC）のナノ周期 積層膜}

グラファイトと六方晶構造の窒化ボロンからなるナノ周期 積層固体潤滑膜を形成するため低バイアス電圧で $\mathrm{C} / \mathrm{BN}$ の ナノ周期積層膜を形成した。トライボメータで評価した $\mathrm{C} / \mathrm{BN}$ ナノ周期積層膜の室温, $200^{\circ} \mathrm{C}$ ではカーボン膜に比 べ，ナノ周期積層膜は低摩擦を示す。特に $4 \mathrm{~nm}$ 周期の積層 膜は低摩擦を示す。更に $400^{\circ} \mathrm{C}$ の条件でも Fig. 18に示す様 に，DLC 膜では 150 回までは $\mu \fallingdotseq 0.2$ と低いが，300回では 0.4 程度に上昇している。 600 回以上では $\mu=0.6$ 程度となっ ている。一方， $4 \mathrm{~nm}$ 周期の $(\mathrm{C} / \mathrm{BN}) \mathrm{n}$ 積層膜では 450 回ま で $\mu \fallingdotseq 0.2$ と低い值を示している. この様に適切な周期を選 べばナノ周期積層膜を形成することにより高温でも低摩擦, 耐摩耗性が改善される21).

自動車の低燃費化を実現するため水素フリーDLC 膜が実 用化されている ${ }^{22)}$ 。さらにエンジンオイル (GMO 添加 PAO）の境界潤滑特性を向上させるために金属を添加した 水素フリーDLC 膜23)を検討している．Fig. 19 亿 TiC/DLC 膜の境界潤滑特性を示す ${ }^{12)}$ 。積層膜はすべての積層周期で 摩擦係数は DLC 単層膜より低い值を示す．その中でも 3,6 ,

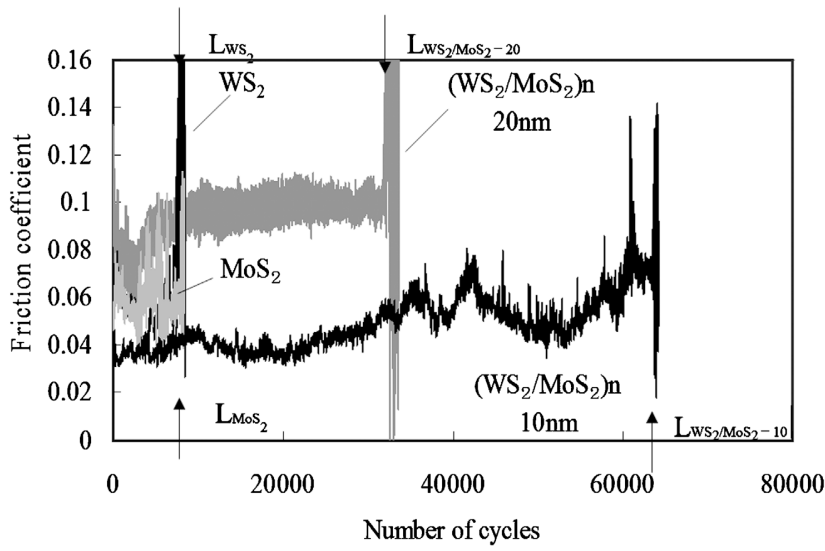

Fig. 17 Friction coefficient of $\mathrm{WS}_{2} / \mathrm{MoS}_{2}$ multilayer film ${ }^{18)}$.

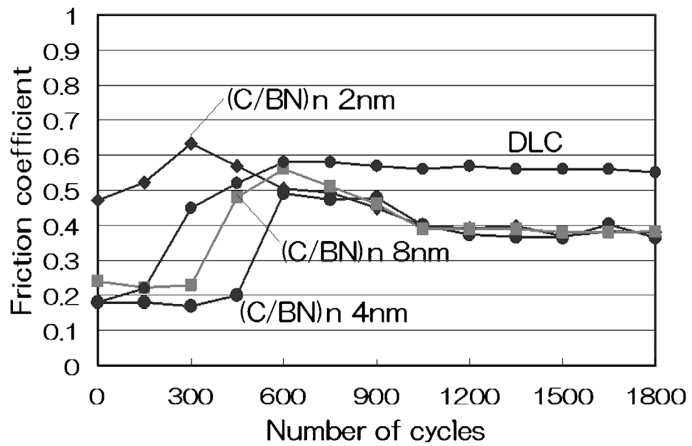

Fig. 18 Friction coefficient of $\mathrm{C} / \mathrm{BN}$ mulatilayer films at $400^{\circ} \mathrm{C}^{21)}$. 


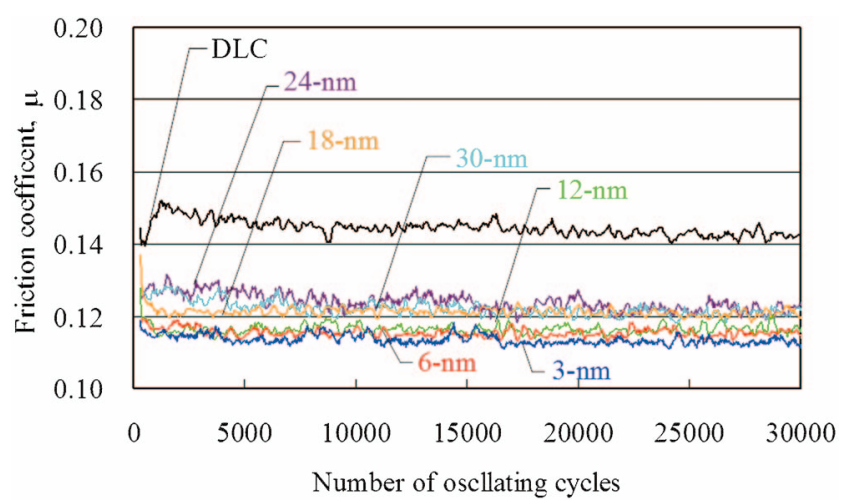

Fig. 19 Friction coefficient of $\mathrm{TiC} / \mathrm{DLC}$ multilayer films dependence on target period ${ }^{12)}$.

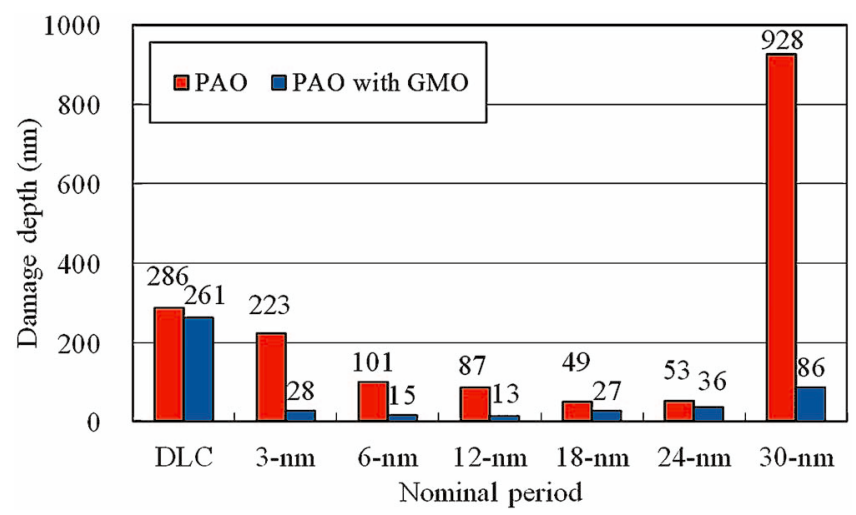

Fig. 20 Damage depth of $\mathrm{TiC} / \mathrm{DLC}$ films after boundary lubrication tests ${ }^{12)}$.

$12 \mathrm{~nm}$ 周期の積層膜の摩擦係数は低い值を示している. Fig. 20に摩耗深さを示す. ナノ周期積層膜 $12,18,24 \mathrm{~nm}$ の摩耗 深さは浅く, 耐摩耗性が得られている.ナノコンポジット, ナノ周期積層膜ともに高硬度で, 低摩擦を示しているが, 耐 摩耗性に関しては周期 $12 \mathrm{~nm}$ 以上のナノ周期積層膜の方が優 れている.これは積層膜の方が膜の厚さ方向に欠陥が進展す るのに対する抑止効果が大きいと考えられる．このように摩 擦条件に適合したナノ構造制御が必要になる.

\section{4. まと め}

ナノ構造制御による固体潤滑膜の摩擦低減, 摩擦耐久性の 向上効果について述べた. ナノ構造を制御した固体潤滑膜は 優れた固体润滑特性を示し, 今後の応用展開が期待できる.

\section{〔文献〕}

1) Solid lubrication handbook, Japanese Society of Tribologists ed. Yokendo, Tokyo, 2010).

2) Y. Enomoto and S. Miyake: Tribology of thin films (University of Tokyo Press, Tokyo, 1994).

3) M. Hirano and S. Miyake: Japanese patent 1930397 (1994).

4) S. Miyake: NEW DIAMOND, 19 (2003) 6.

5) D. Li, X. Chu, S. C. Cheng, X. W. Lin, V. P. Dravid, Y. W. Chung, M. S. Wong and W. D. Sproul: Appl. Phys. Lett., 67 (1995) 203.

6) L. A. Donohue, J. Cawley, D. B. Lewis, J. S. Brooks and W. D. Munz: Surf. Coat. Technol., 76-77 (1995) 149.

7) M. Wang, T. Toihara, M. Sakurai, W. Kurosaka and S. Miyake: Tribol. Int., 73 (2014) 36.

8) S. Miyake: J. Vac. Sci. \& Technol. B, 21 (2003) 785.

9) S. Miyake: Thin Solid Films, 493 (2005) 160.

10) S. Miyake and M. Wang: in New Tribological Ways, T. Ghrib ed. (InTech, Rijeka, Croatia, 2011) p. 71.

11) S. Miyake and W. Kurosaka: Tribologist, 53 (2008) 23.

12) S. Miyake, T. Shindo and M. Suzuki: Surf. Coat. Technol., 221 (2013) 124.

13) S. Miyake, T. Hashizume and Y. Wakatsuki: Surf. Interface Anal., 38 (2006) 873.

14） S. Miyake, Y. Sekine and S. Watanabe: Trans. Jpn. Soc. Mech. Eng., 65 (1999) 4496.

15) S. Miyake, T. Shindo and Y. Saito: Tribology-Materials, Surfaces \& Interfaces, 5 (2011) 114.

16) S. Miyake, M. Komiya and T. Shindo: Tribol. Lett., 46 (2012) 1.

17) S. Miyake and T. Shindo: Thin Solid Films, 527 (2013) 210.

18) S. Miyake, Y. Sekine, J. Noshiro and S. Watanabe: Jpn. J. Appl. Phys., 43 (2004) 4338.

19) S. Watanabe, J. Noshiro and S. Miyake: Surf. Coat. Technol., 188-189 (2004) 644.

20) J. Noshiro, S. Watanabe, T. Sakurai and S. Miyake: Surf. Coat. Technol., 200 (2006) 5849.

21) S. Miyake, T. Hashizume, W. Kurosaka, M. Sakurai and M. Wang: Surf. Coat. Technol., 202 (2007) 1023.

22) S. Miyake, Y. Yasuda, M. Kano and Y. Mabuchi: Japanese patent 3555844 , U.S. patent 6844068 , DE patent 10017459 C2 (2002).

23) S. Miyake, T. Saito, Y. Yasuda, Y. Okamoto and M. Kano: Tribol. Int., 37 (2004) 751. 